MaPan : Jurnal Matematika dan Pembelajaran

p-ISSN: 2354-6883 ; e-ISSN: 2581-172X

Volume 8, No 1, June 2020 (35-48)

DOI: https://doi.org/10.24252/mapan.2020v8n1a3

\title{
DISCOVERY LEARNING MODEL AS A SOLUTION TO DEVELOP STUDENTS' UNDERSTANDING IN MATRIX CONCEPT
}

\author{
Sri Nadia Khairunnisa1), Harry Dwi Putra2), Eka Senjayawati3) \\ 1,2,3Program Studi Pendidikan Matematika, Institut Keguruan dan Ilmu Pendidikan \\ (IKIP) Siliwangi \\ 1,2,3Jl. Terusan Jenderal Sudirman, Cimahi \\ E-mail: srinadiakhairunnisa@gmail.com ${ }^{1)}$, harrydp.mpd@gmail.com²), \\ senja_eka@yahoo.co.id 3 )
}

Received April 18, 2020; Revised June 02, 2020; Accepted June 05, 2020

\begin{abstract}
:
This study aims to examine the increasing mastery of the concept of the matrix through the Discovery Learning model. This research is a class action research. The subjects in this study were students of Class XI TEDK-A at SMK Negeri 1 Cimahi. Data sources are teachers and students. Data collection techniques using tests and observation sheets. Based on data analysis, the average of student learning outcomes has increased by 77.42 , from the first test cycle achieved by 10.00 to the last testing cycle achieved by 87.42. From the results, it can be concluded that there is an improvement in students' mathematical understanding of the matrix material in class XI TEDK-A in SMK Negeri 1 Cimahi students who use the discovery learning model.
\end{abstract}

Keywords: Concept Understanding, Matrix, Discovery Learning

\section{PENERAPAN MODEL DISCOVERY LEARNING UNTUK MENINGKATKAN PEMAHAMAN KONSEP SISWA PADA MATERI MATRIX}

\begin{abstract}
Abstrak:
Penelitian ini bertujuan untuk menguji apakah penguasaan konsep matriks melalui model Discovery Learning dapat ditingkatkan. Jenis penelitian ini adalah penelitian tindakan kelas. Subjek dalam penelitian ini adalah siswa kelas XI TEDK-A di SMK Negeri 1 Cimahi. Sumber data diperoleh dari guru dan siswa. Teknik pengumpulan data menggunakan tes dan lembar observasi. Berdasarkan analisis data, rata-rata hasil belajar siswa meningkat sebesar 77,42 dari siklus tes pertama yang dicapai sebesar 10,00 hingga siklus pengujian terakhir yang dicapai oleh 87,42. Dari hasil penelitian dapat disimpulkan bahwa terdapat peningkatan pemahaman matematis siswa pada materi matriks siswa kelas XI TEDK-A di SMK Negeri 1 Cimahi dengan menggunakan model Discovery Learning.
\end{abstract}

Kata kunci: Pemahaman Konsep, Matrix, Discovery Learning 
How to Cite: Khairunnisa, S. N., Putra, H. D., \& Senjayawati, E. (2020). Discovery Learning Model as A Solution to Develop Students' Understanding in Matrix Concept. MaPan: Jurnal Matematika dan Pembelajaran, 8(1), 35-48. https://doi.org/10.24252/mapan.2020v8n1a3.

\section{INTRODUCTION}

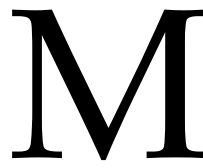

athematics is a subject that exists at the level of formal school education. Not a few people in the community who judge mathematics is a difficult subject to master, especially by students (Liberna, 2015). In the learning process, students will have difficulty continuing their education to a higher level if they can not understand mathematical concepts in their previous education (Larasati \& Suparman, 2018). The role of the concept itself is crucial in mathematics because the concept is the basis of the thought process and the basis for formulating further concepts (Gilmore, Clayton, Cragg, Mckeaveney, Simms, \& Johnson, 2018). According to this view, The concept of learning is one of the fundamental interconnected aspects of mathematics, so constructively that understanding the concept needs to be built and used as a foundation for learning (Dominguez-Rue \& Mrotzek, 2013).

Understanding concepts is the basis for solving mathematical problems so that each student must have sufficient concept understanding skills to be able to solve problems in mathematics (Nurdin, Ma'aruf, Amir, Risnawati, Noviarni, \& Azmi, 2019). Salimi (Fahrudhin, Zuliana, \& Bintoro, 2018) explained indicators of understanding concepts including (1) defining concepts verbally and in writing; (2) making examples and non-examples of denial; (3) presenting a concept with models, diagrams, and symbols; (4) changing one form of representation to another; (5) recognizing the meaning and interpretation of concepts; (6) identifying the characteristics of a concept; and (7) comparing and differentiating concepts. To achieve understanding of mathematical concepts is not an easy thing for students because understanding of these concepts is owned individually. Meanwhile, according to Ruseffendi (Herdiwibawa, Jamiah, \& Hamdani, 2019) at this time student's understanding of mathematical concepts is still low, even not a few students who are unable to understand existing concepts after learning mathematics, many concepts are misunderstood so that mathematics is considered as difficult science. This assumption is, what can unwittingly even have influenced the mindset of students. This can be seen from the student's learning achievement, which is not satisfying. This is likely due to 
the subject matter in mathematics, which is increasing from every level, from concrete to abstract.

Results of a 2011 study conducted by the Trens in International Mathematics and Science Study (TIMSS) indicated that the dominance of the ability of students in Indonesia to memorize formulas or concepts in mathematics learning is one of the causes of the decline in the achievement of student learning outcomes in mathematics education. The results of the Trends in International Mathematics and Science Study (TIMSS) study show that Indonesian students are ranked low in several abilities, one of which is the ability to understand complex information and mastery of concepts and problem solving (Winaryati, Fathurohman, \& Iriyanto, 2015).

In Indonesia, mathematics is taught starting from elementary school to high school. The stages of learning gradually start from concrete mathematics to the abstract stage, which is applied in secondary school mathematics. According to Hidayat (Rudyanto, 2014), educational curricula that have been implemented in Indonesia include the 1952, 1964, 1968, 1975/1976, 1989, 1994 curriculum supplements 1999, KBK 2004, KTSP 2006, and the curriculum that applies to date is the 2013 curriculum. By the 2013 curriculum, in secondary schools Vocational (SMK), one of the mathematics teaching materials delivered is a matrix.

In SMK, the matrix is taught to students with the subject of matrices and matrix similarities, operations on matrices, matrix determinants, and matrix inverses. Understanding the concept of the matrix is very necessary for its sustainability in other materials. One of them, the concept of the matrix is necessary for its sustainability as one of the prerequisites in the material of geometry transformation, where the indicator of achievement competence is to find the concept of transformation concerning the concept of the matrix (Manullang, Kristianto, Hutapea, Sinaga, Sinaga, Marianus, \& Sinambela, 2017). Students in the process of trying to understand the concept of the matrix will determine the acquisition of learning achievement expressed in the test scores of the matrix material, mathematics learning achievement of students in the subject matter of matrix is a special learning achievement (Sulistyawan, 2018). Research conducted by Herdiwibawa, Jamiah, \& Hamdani (2019) shows that understanding the concept of matrices is very good for students with a high level of mathematics skills, and students with intermediate skills have students who have not been able to understand the concept well so that students are unable to complete the operation of the matrix. Therefore, the definition of 
matrix operations is necessary to understand. With so many concepts contained in this matrix material, so to understand it, students need more visualization of the concepts. It also causes difficulties in students' understanding.

Based on observations conducted at one of the Vocational Schools in Malang, when learning mathematics classes, the learning atmosphere is less conducive, the learning system focused on the teacher, and interaction between teacher and students is dominated by high achieving students (Fauziah, Parta, \& Raharjo, 2016). Previous research at SMK 2 Muhammadiyah Bandar Lampung showed that most students did not take the lead in understanding concepts and arithmetic operations on matrices. Students tended to follow the concepts and calculation formulas given by their teachers so that the impact on student achievement was less than optimal (Pratiwi, Hasyim, \& Caswita, 2015). Then, the researchers conducted a preliminary study to students of SMK Negeri 1 Cimahi, who were students one level higher than the class to be conducted research. The result, states that students experience errors in solving matrix problems, the success of students in working on the problem no more than $30 \%$ of the total value that might be $100 \%$ correct, more clearly as follows:

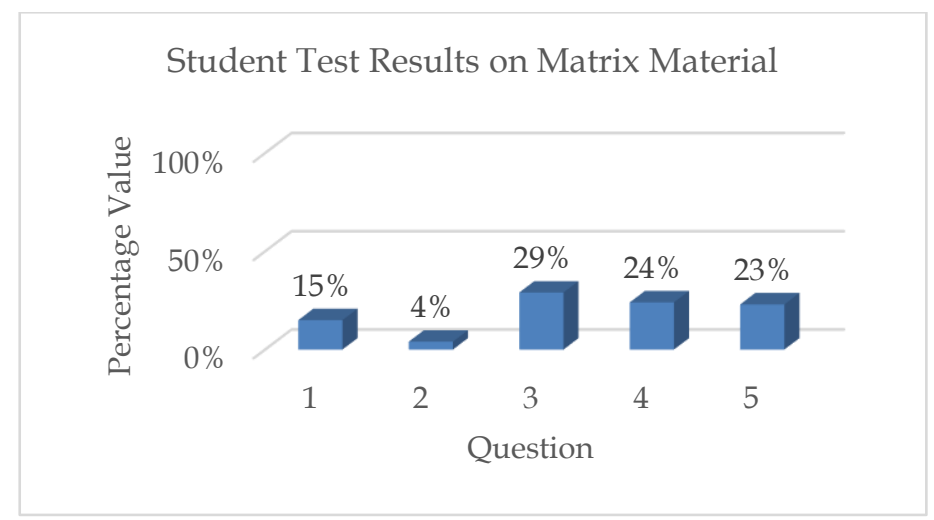

Figure 1. Percentage of Matrix Material Test Results

Based on several factors above, It shows that improving students' understanding of mathematical concepts requires improving learning mathematics itself. Given the importance of mathematics, the process of learning by teachers needs to be improved, namely by implementing a learning model that can improve understanding of mathematical concepts. In this 2013 Curriculum, it is clearly outlined that teachers must carry out learning with a scientific approach. The scientific approach to learning includes five main learning experiences, namely observing, asking questions, gathering 
information/trying, associating/reasoning, and communicating, by the Ministry of Education and Culture (Sani, 2015). To help minimize student difficulties that occur by using innovations that can improve student learning outcomes, one of which is by discovery learning that accompanies scientific approaches to classroom learning.

In a previous study conducted at one of SMK in Semarang in 2013/2014, it resulted that discovery learning was very effective in mathematics learning with the implementation of the 2013 curriculum, which had a scientific approach (Dina, Mawarsari, \& Suprapto, 2015). The research conducted by Dina et al. stated that the ability of students who were given learning with the discovery learning model of the scientific approach to the Curriculum 2013 implementation was better than the ability of students with conventional learning. Furthermore, research conducted by Pratiwi at one of SMK in Bandar Lampung, gave the results of the learning process with the discovery learning model to increase student activity in learning, as well as the completeness of student learning outcomes on the matrix material reached $82.53 \%$ (Pratiwi, Hasyim, \& Caswita, 2015).

Discovery Learning is a problem-solving model that will benefit students in their lives later on. Discovery learning is learning with discovery activities to understand the main ideas of a scientific discipline that are actively carried out by individuals or students themselves, while the teacher's role is to encourage students in their discovery process to gain an independent learning experience (Mahmoud \& Abdelrahman, 2014). Therefore, according to Illahi (Dina, Mawarsari, \& Suprapto, 2015), in the learning process that uses discovery learning models using activities and experiences directly so provide a more realistic learning atmosphere, making learning more attractive to students' attention and enabling the meaning obtained in the formation of abstract concepts in their learning. Furthermore, learning with the discovery learning method is a learning process by conveying ideas resulting from the discovery process (Gupta, Akhtar, \& Srivastava, 2012). The Discovery learning model also provides many opportunities for students to be directly involved in their learning activities because these activities are tailored to the interests and needs of students themselves so that these activities will further arouse student learning motivation.

Stages of learning with discovery learning model include observing (finding problems), formulating problems, proposing hypotheses, planning problem solving through experiments or other means, carrying out observations 
and data collection, data analysis, and concluding experiments that have been carried out or discovered. Through the discovery learning model, in addition to enhancing the experience of students, this learning also makes students closer to the source of their learning, then it will increase students' self-confidence because students discover what they understand themselves, as well as foster and enhance a sense of cooperation with their friends (Putrayasa, Syahruddin, \& Margunayasa, 2014).

Previously there had been researched on Discovery Learning conducted at the Vocational School on geometry material by (Dina, Mawarsari, \& Suprapto, 2015), resulting that discovery learning was very effective in mathematics learning with the implementation of the Curriculum 2013 which had a scientific approach. Then, research conducted by Ramziah (2016) results that an increase in learning outcomes and student activities in solving problems given to the matrix material through learning activities using a scientific approach. Based on these things, to find out the effectiveness of discovery learning in the implementation of the 2013 Curriculum for matrix material in Vocational Schools, the researchers intend to conduct further research using Classroom Action Research in one of the XI classes in SMK Negeri 1 Cimahi. Researchers use the research title, "The Application of Discovery Learning Model to Improve the Understanding of Matrix Concepts in Class XI Students of TEDK-A SMK Negeri 1 Cimahi".

\section{RESEARCH METHOD}

The type of research carried out is Classroom Action Research, which aims to develop new skills or new approaches to solving problems with the direct application of the world of work or the actual world. The subjects in this study were students of class XI TEDK-A SMK Negeri 1 Cimahi, which numbered 30 students, where male students amounted to 15 people and 15 female students with the subject of the matrix. This research was conducted in November 2019 with details, namely the preparation of learning tools, implementation, and preparation of reports. This research was conducted in four stages, namely: (1) Planning, (2) Implementation, (3) Observations, and (4) Reflection (Puspitadewi, Saputro, \& Ashadi, 2016). In the planning stage, researchers plan a discovery learning model that will be applied in the learning process with the subject matter of the matrix, develop learning scenarios, prepare student worksheets, and prepare an evaluation form and learning observation sheet. In the action phase, the researcher applies the learning action 
referring to the scenario that has been prepared. At the observation stage, conduct observations using the observation format, assessing the results of actions using the evaluation format. Then in the reflection stage, reviewing the observations of the research subjects. This research was conducted in conjunction with learning activities using discovery learning models. The stages of learning with the discovery learning model include (1) stimulus, students are given problems to bring up the desire to investigate themselves; (2) identification of problems, provide opportunities for students to identify problems encountered; (3) data collection, students are directed to find something related to the problems faced by reading or questioning; (4) data processing, students try to develop concepts and generalizations using collected data; (5) verify, students carry out careful checks to prove the concepts found; and (6) concludes, students conclude from the findings.

This research is planned in one cycle because it adjusts to the mathematics syllabus of SMK Negeri 1 Cimahi. Besides, in this provision, a cycle of action learning completeness student learning outcomes have been fulfilled, so that research is carried out sufficiently until cycle one. The initial action in this study was to conduct a preliminary test to find out the improvement in student learning outcomes. After that, do learning by using discovery learning as many as three meetings. Then students are given a final test at the last meeting.

The instruments used in this study include (1) Teacher and student observation sheets used to measure teacher and student attitudes throughout the learning process, adapted to the learning scenario in the 2013 Curriculum RPP scientific approach to the discovery learning model; (2) The written test consists of 5 matrix questions which, adopted from national exam questions, are used to measure students' understanding of mathematical concepts on the subject matter of the matrix. As for measuring students' understanding of concepts using indicators include (1) defining concepts verbally and in writing; (2) presenting a concept with models, diagrams, and symbols; (3) recognizing the meaning and interpretation of concepts; (4) identifying the characteristics of a concept; and (5) comparing and differentiating concepts.

Data collection methods used by researchers for classroom action research are written test methods and observation methods. The observer of this study was a mathematics teacher in class XI TEDK-A. Meanwhile, data analysis techniques used are test result data and observation results data of the teacher and students. 


\section{RESULTS AND DISCUSSION}

The results of this study consisted of data on teacher teaching activities and student learning activities as well as student final test results on the subject matter of the matrix. The details of data exposure are as follows:

a) Observation Results of Teacher Teaching Activities

The observation sheet for teacher teaching activities is used to evaluate teacher's teaching activities in learning matrix material by applying Discovery Learning steps. At the class meeting, observers pay attention to the teacher's learning process by applying the Discovery Learning model consisting of (1) stimulus; (2) problem identification; (3) data collection; (4) data processing; (5) verification; and; (6) conclusion.

A description of the recapitulation of the suitability of teacher activity in the implementation of the discovery learning scenario can be seen in table 1 .

Table 1. Recapitulation of Observations on Teacher's Activities

\begin{tabular}{ccccc}
\hline Aspect & \multicolumn{3}{c}{ Meeting (\%) } & Average \\
\hline Stimulus & 1 & 2 & 3 & \\
Problem & $33 \%$ & $33 \%$ & $33 \%$ & $33 \%$ \\
Identification & $60 \%$ & $80 \%$ & $80 \%$ & $73 \%$ \\
Data Collection & $50 \%$ & $75 \%$ & $75 \%$ & $67 \%$ \\
Data Processing & $60 \%$ & $80 \%$ & $80 \%$ & $73 \%$ \\
Verify & $25 \%$ & $25 \%$ & $25 \%$ & $25 \%$ \\
Concludes & $25 \%$ & $25 \%$ & $25 \%$ & $25 \%$ \\
\hline Average & $42 \%$ & $53 \%$ & $53 \%$ & \\
\hline
\end{tabular}

Based on observations of teacher teaching activities, it was found that the first aspect was implemented with an average percentage of $33 \%$ included in the sufficient category, namely when the teacher held an apperception and reaffirmed the concept of the matrix that students had learned. The second, third, and fourth aspects are implemented with an average percentage above $50 \%$ included in the good category, namely by the activities of the teacher guiding student discussions, asking students to find information to solve problems, and allowing students to criticize the results of the presentation.

In the fifth aspect, it included in the category of less with an average percentage of $25 \%$ because, in the implementation, the teacher only asks students to check back the answers temporarily. The last aspect is also 
categorized less with an average percentage of $25 \%$ because the teacher does not allow students to conclude the material taught, but the teacher and students summarize the results of the discussion together.

Based on data obtained from the first cycle, it can be concluded that the achievement of the implementation of teaching activities through the application of Discovery Learning model for aspects of teacher activity categorized sufficiently.

b) Observation Results of Students Learning Activities

The observation sheet for students learning activities is used to determine students' learning activities. At the class meeting, observers pay attention to students' activities in the learning process by applying the Discovery Learning model which consists of (1) stimulus; (2) problem identification; (3) data collection; (4) data processing; (5) verify; and (6) conclusion. A description of the recapitulation of the suitability of the implementation of the discovery learning scenario to student activity can be seen in table 2 .

Table 2. Recapitulation of Observations on Students Activity

\begin{tabular}{ccccc}
\hline Aspect & \multicolumn{3}{c}{ Meeting (\%) } & Average \\
\hline Stimulus & 1 & 2 & 3 & \\
Problem & $33 \%$ & $33 \%$ & $33 \%$ & $33 \%$ \\
Identification & $60 \%$ & $80 \%$ & $80 \%$ & $73 \%$ \\
Data Collection & $50 \%$ & $75 \%$ & $75 \%$ & $67 \%$ \\
Data Processing & $60 \%$ & $80 \%$ & $80 \%$ & $73 \%$ \\
Verify & $25 \%$ & $25 \%$ & $25 \%$ & $25 \%$ \\
Concludes & $25 \%$ & $25 \%$ & $25 \%$ & $25 \%$ \\
\hline Average & $42 \%$ & $53 \%$ & $53 \%$ & \\
\hline
\end{tabular}

Based on observations of students learning activities, it is found that the first aspect is implemented with an average percentage of 33\% included in the sufficient category, namely when students actively respond in apperception activities and pay attention to the teacher's explanation of the matrix concept. The second, third, and fourth aspects are implemented with an average percentage above $50 \%$ included in the good category, namely by working on exercises, finding information from books or the internet processing data from information that has been found, and students criticizing the results of the presentation. In the fifth aspect, included in the category of less with an average 
percentage of $25 \%$ because the implementation is only students check the answers temporarily. The last aspect is also categorized less with an average percentage of $25 \%$ because students and teachers summarize the results of the discussion.

Based on the data achieved from this first cycle, it can be concluded that the application of Discovery Learning model applied by the teacher to aspects of students' activity is sufficiently categorized.

After implementing the learning process, the final test is conducted to see an increased understanding of the mathematical concepts of students. The results of the descriptive analysis of the scores of student learning outcomes after the action was implemented showed an understanding of the mathematical concepts of students in the matrix material of 30 students obtaining an average score of 87.42, with the highest score being 100 and the lowest score being 61.36. The understanding improvement of mathematical concepts class XI TEDK-A SMK Negeri 1 Cimahi for each item matrix is shown in table 3.

Table 3. Improved Understanding of Student Matrix Concepts

\begin{tabular}{cccc}
\hline $\begin{array}{c}\text { Question } \\
\text { Number }\end{array}$ & $\begin{array}{c}\text { The score of Initial } \\
\text { Test }\end{array}$ & $\begin{array}{c}\text { The score } \\
\text { of the } \\
\text { Final Test }\end{array}$ & Increase \\
\hline 1 & 23,33 & 86,11 & 62,78 \\
2 & 7,50 & 95,00 & 87,50 \\
3 & 1,00 & 91,67 & 90,67 \\
4 & 2,22 & 81,85 & 79,63 \\
5 & 19,09 & 83,33 & 64,24 \\
Average & 10,00 & 87,42 & 77,42 \\
\hline
\end{tabular}

From table 3, it appears that for each item, the problem has experienced a significant increase, and it appears that the average grade value for each item is included in the complete category with a value of 87.42 above the minimum completeness criteria determined by SMK Negeri 1 Cimahi. Description of the frequency distribution and percentage of completeness of students' mathematics learning outcomes after the implementation of discovery learning models in cycle I can be seen from table 4 . 
Table 4. Frequency Distribution and Completeness Presentation of Student Mathematics Learning Outcomes

\begin{tabular}{cccc}
\hline Score & Category & Frequency & Percentage \\
\hline $0-60$ & Not complete & 0 & $0 \%$ \\
$61-100$ & Complete & 30 & $100 \%$ \\
& Total & 30 & $100 \%$ \\
\hline
\end{tabular}

Table 4 shows that all students of class XI TEDK-A SMK Negeri 1 Cimahi, as many as 30 students $(100 \%)$ have completed their learning outcomes on mathematics subject matter of matrix. It means that in the first cycle, the completeness of learning outcomes after taking action research with the Discovery Learning model has been achieved because the number of students who have completed learning is $100 \%$. The completeness of the learning outcomes shows that students have increased their ability to understand mathematical concepts in the subject of the matrix.

Student learning outcomes that have been obtained after the implementation of the cycle I in learning mathematics of matrix material by applying the Discovery Learning model, the average score obtained was 87.42 with a score as high as 100, and the lowest score was 61.36 from an ideal score of 100, and 30 students completed their learning outcomes $(100 \%)$. This result is aligned with research conducted by Pratiwi, Hasyim, \& Caswita (2015), which states that students' learning completeness with discovery learning models reaches $82.53 \%$, and the learning process with discovery learning models increases student activity in the mathematics learning process.

The success of the implementation of the classroom action research conducted is because the teacher can implement the learning design properly following the steps of applying the Discovery Learning model. Besides, research by Pratiwi, Hasyim, \& Caswita (2015) discovered that the learning process had increased students learning activities such as reading, listening to explanations, discussing, solving problems, presenting the results of group discussions, and others. Thus, increasing student mathematics learning outcomes in class XI TEDK-A SMK Negeri 1 Cimahi due to good cooperation in student learning groups and guidance and direction from the teacher. So the facts can prove that the application of the Discovery Learning model can improve learning outcomes as a form of mastery of mathematical concepts, especially in solving problems of the matrix material. This finding is consistent with research from Hamzah \& Mahmudah (2012), which states that students' understanding of 
mathematical concepts is influenced by learning activities by $85.4 \%$, while the remaining $14.6 \%$ is influenced by other factors besides learning activities.

\section{CONCLUSION}

Based on the results and discussion, it can be concluded that the discovery learning model can improve the matrix concept understanding of class XI TEDK-A students of SMK Negeri 1 Cimahi. Likewise, there was a significant increase both in teacher teaching activities and student learning activities in mathematics learning by applying the Discovery Learning model based on several teacher teaching activities and student learning activities observed. The improvement of students learning outcomes in class XI TEDK-A SMK Negeri 1 Cimahi due to good cooperation in learning groups and teacher guidance and direction. Increasing understanding of students matrix concepts is then shown by the average value of mathematics learning outcomes with matrix material in the first cycle in the completeness category, assessment using a description test on matrix material with completeness obtained by all students $(100 \%)$ in class XI TEDK-A SMK Negeri 1 Cimahi. Judging from the process of learning and learning outcomes test of the first cycle that has been achieved, the student's scores showed an increase from the average on the initial test was 10 , and the average score of the final test was 87.42 .

\section{REFERENCES}

Dina, A., Mawarsari, V. D., \& Suprapto, R. (2015). Implementasi kurikulum 2013 pada perangkat pembelajaran model discovery learning pendekatan scientific terhadap kemampuan komunikasi matematis materi geometri SMK. JKPM (Jurnal Kajian Pendidikan Matematika), 2(1), 22-31. https:// doi.org/10.26714/jkpm.2.1.2015.\%25p.

Dominguez-Rue, E., \& Mrotzek, M. (2013). Conceptualizing the Aesthetic Experience: Using the influence matrix to show causal relationships between basic concepts in aesthetics. International Journal of General Systems, 43(1), 19-31. https:/ / doi.org/10.1080/03081079.2013.848356.

Fahrudhin, A. G., Zuliana, E., \& Bintoro, H. S. (2018). Peningkatan pemahaman konsep matematika melalui realistic mathematic education berbantuan alat peraga bongpas. Jurnal Ilmiah Pendidikan Matematika, 1(1), 14-20. https://doi.org/10.24176/ anargya.v1i1.2280.

Fauziah, K., Parta, I. N., \& Raharjo, S. (2016). Pengembangan lembar kerja siswa materi perkalian matriks bercirikan penemuan terbimbing untuk siswa SMK Kelas X. Jurnal Pendidikan: Teori, Penelitian, dan Pengembangan, 1(9), 1721-1729. https://doi.org/10.17977/jp.v1i9.6735. 
Gilmore, C., Clayton, S., Cragg, L., Mckeaveney, C., Simms, V., \& Johnson, S. (2018). Understanding arithmetic concepts: The role of domain-specific and domain-general skills. PLOS ONE, 13(9), 1-20. https://doi.org /10.17028/rd.lboro.5446561.

Gupta, T., Akhtar, M. J., \& Srivastava, K. V. (2012). Development of the virtual lab module for understanding the concepts of electric and magnetic field patterns in rectangular waveguides and cavities. International Journal of Online Engineering, 8(3), 12-21. Retrieved from https:// onlinejour.journals.publicknowledgeproject.org/in-depth/i-joe/article/ view/2113.

Hamzah, M., \& Mahmudah, N. Q. (2012). Pengaruh aktivitas belajar terhadap pemahaman konsep matematika siswa di MTs Salafiyah Kota Cirebon. Mathematics Education Learning and Teaching, 1(2), 1-13. https:/ / doi.org/ 10.24235/eduma.v1i2.293.

Herdiwibawa, J. P., Jamiah, Y., \& Hamdani. (2019). Pemahaman konseptual siswa dalam menyelesaikan soal materi invers matriks pada kelas XI SMAN 8 Pontianak. Jurnal Pendidikan dan Pembelajaran Khatulistiwa, 8(10), 1-8. Retrieved from http://jurnal.untan.ac.id/index.php/jpdpb/ article/view/37202.

Larasati, S., \& Suparman. (2018). Design of mathematics module development based on guided discovery methods to improve understanding of concept of class X SMA /MA. International Summit on Science, Technology, and Humanity (ISETH 2018), 201-214. Retrieved from http:/ / hdl.handle.net/ 11617/11677.

Liberna, H. (2015). Peningkatan kemampuan berpikir kritis matematis siswa melalui penggunaan metode improve pada materi sistem persamaan linear dua variabel. Formatif: Jurnal Ilmiah Pendidikan MIPA, 2(3), 190-197. https:/ / doi.org/10.30998/ formatif.v2i3.101.

Mahmoud, \& Abdelrahman, K. (2014). The effect of using discovery learning strategy in teaching grammatical rules to first year general secondary student on developing their achievement and met cognitive skills. International Journal of Innovation and Scientific Research, 5(2), 146-153. Retrieved from http://www.ijisr.issr-journals.org/abstract.php?article= IJISR-14-153-06.

Manullang, S., Kristianto, A., Hutapea, T. A., Sinaga, L. P., Sinaga, B., Marianus, M., \& Sinambela, P. N. J. M. (2017). Buku guru Kementerian Pendidikan dan Kebudayaan (Revisi; A. Lukito, M. D. M, Turmudi, \& N. Priatna, eds.). Jakarta: Pusat Kurikulum dan Perbukuan, Balitbang, Kemendikbud.

Nurdin, E., Ma'aruf, A., Amir, Z., Risnawati, Noviarni, \& Azmi, M. P. (2019). Pemanfaatan video pembelajaran berbasis geogebra untuk meningkatkan kemampuan pemahaman konsep matematis siswa SMK. Jurnal Riset Pendidikan Matematika, 6(1), 87-98. https:/ / doi.org/10.21831/ 
jrpm.v6i1. 18421.

Pratiwi, E., Hasyim, A., \& Caswita. (2015). peningkatan hasil belajar matematika siswa melalui model pembelajaran discovery di kelas X SMK Muhammadiyah 2 Bandar Lampung. Jurnal Teknologi Informasi Komunikasi Pendidikan, 3(2). Retrieved from http:// jurnal.fkip.unila.ac.id/index.php/JT/article/view/7851.

Puspitadewi, R., Saputro, A. N. C., \& Ashadi. (2016). Penerapan model pembelajaran discovery learning untuk meningkatkan minat dan prestasi belajar siswa pada materi kelarutan dan hasil kali kelarutan kelas XI MIA 3 semester genap SMAN 1 Teras tahun pelajaran 2015/2016. Jurnal Pendidikan Kimia (JPK), 5(4), 114-119. Retrieved from https:// jurnal.fkip. uns.ac.id/index.php/kimia/article/view/9361/6929.

Putrayasa, I. M., Syahruddin, H., \& Margunayasa, I. G. (2014). Pengaruh model pembelajaran discovery learning dan minat belajar terhadap hasil belajar IPA siswa. Jurnal Mimbar PGSD Universitas Pendidikan Ganesha, 2(1). https://doi.org/10.23887/jjpgsd.v2i1.3087.

Ramziah, S. (2016). Peningkatan kemampuan representasi matematis siswa kelas X2 SMAN 1 Gedung Meneng menggunakan bahan ajar matriks berbasis pendekatan saintifik. Mosharafa: Jurnal Pendidikan Matematika, 5(2), 138-147. https://doi.org/10.31980/mosharafa.v5i2.269.

Rudyanto, H. E. (2014). Model Discovery learning dengan pendekatan saintifik bermuatan karakter untuk meningkatkan kemampuan berpikir kreatif. Premiere Educantum: Jurnal Pendidikan Dasar dan Pembelajaran, 4(1), 41-48. https://doi.org/10.25273/ pe.v4i01.305.

Sani, A. H. (2015). Pembelajaran matematika berbasis pendekatan saintifik dan kaitannya dengan menumbuhkan keterampilan berpikir tingkat tinggi. Prosiding Seminar Nasional Matematika dan Pendidikan Matematika UNY 2015. Yogyakarta.

Sulistyawan, A. E. (2018). Hubungan intensitas latihan dan kompetensi guru dalam meningkatkan prestasi belajar matematika materi matriks siswa Kelas XI Semester Gasal SMK N 1 Warureja tahun pelajaran 2017/2018. Jurnal Pendidikan MIPA Pancasakti, 2(1), 43-49. https:/ / doi.org/10.24905/ jpmp.v2i1.877.

Winaryati, E., Fathurohman, A., \& Iriyanto, S. (2015). developmen model pembelajaran "wisata lokal" Kabupaten Rembang, Jawa Tengah. Jurnal Pendidikan Sains Universitas Muhammadiyah Semarang, 3(1), 34-42. https:// doi.org/10.26714/jps.3.1.2015.34-42. 